\title{
PERTANIAN, KEHUTANAN DAN PERIKANAN SEBAGAI SEKTOR BASIS PEREKONOMIAN KABUPATEN ACEH TENGGARA TAHUN 2014-2018
}

\author{
Bahrul Ilmi ${ }^{*}$ \\ ${ }^{1}$ Program Studi Hukum Ekonomi Syari'ah, Sekolah Tinggi Agama Islam Sepakat \\ Segenep Kutacane. \\ *Korespondensi penulis: biselian@gmail.com
}

(Submission 31-03-2021, Revission 03-05-2021, Accepted 04-06-2021)

\begin{abstract}
This study aims to see changes in the Agriculture, Forestry and Fisheries Sector in the economy of Southeast Aceh District. The role of the Agriculture, Forestry and Fisheries Sector as the basis of the sector in the economy of Southeast Aceh District. The data collected is secondary data sourced from agencies related to research in the scope of Aceh Tenggara District. The results of the analysis show that the Agriculture, Forestry and Fisheries sectors were identified as a yearly sector analysis basis, with the highest $L Q$ value of 43, 19 in 2014 and the lowest LQ value of 40.66 in 2018. Aceh Tenggara district with the highest 1.3 billion in 2017 and the lowest 1.2 billion in 2014 .
\end{abstract}

Keywords: agriculture, forestry, fisheries, southeast aceh economic base sector, location quotient.

\begin{abstract}
Abstrak
Penelitian ini bertujuan untuk mengetahui perubahan Sektor Pertanian, Kehutanan, dan Perikanan dalam perekonomian Kabupaten Aceh Tenggara. Peran Sektor Pertanian, Kehutanan, dan Perikanan sebagai sektor basis dalam perekonomian Kabupaten Aceh Tenggara. Data yang dikumpulkan adalah data sekunder yang bersumber dari instansi terkait dengan penelitian ini pada lingkup Kabupaten Aceh Tenggara. Hasil analisis menunjukan bahwa sektor Pertanian, Kehutanan dan Perikanan yang teridentifikasi sebagai sektor basis salama tahun analisis, dengan nilai LQ tertinggi 43, 19 Tahun 2014 dan nilai LQ terendah 40,66 tahun 2018. Sumbangan Sektor Pertanian, Kehutanan dan Perikanan dan sub-sub sektornya terhadap Kabupaten Aceh Tenggara yang tertinggi sebesar 1, 3 millyar tahun 2017 dan yang terendah sebesar 1,2 millyar tahun 2014.
\end{abstract}

Kata kunci: pertanian, kehutanan, perikanan, sektor basis perekonomian aceh tenggara, hasil bagi lokasi

\section{PENDAHULUAN}

Indonesia dikenal sebagai negara agraris, sehingga mengandalkan sektor pertanian, kehutanan dan perikanan baik sebagai sumber mata pencaharian maupun sebagai penopang pembangunan. Sektor pertanian, kehutanan dan perikanan 
meliputi subsektor tanaman bahan makanan, subsektor holtikultura, subsektor perikanan, subsektor peternakan, dan subsektor kehutanan.

Kabupaten Aceh Tenggara memiliki potensi ekonomi yang besar di bidang pertanian, kehutanan dan perikanan terlihat dari dominannya profesi masyarakat di bidang itu. Di samping itu, kebijakan pembangunan di bidang pertanian, kehutatan dan perikanan ditekankan terutama pada pengembangan sumberdaya pertanian, kehutanan, dan perikanan yang meliputi sumber daya manusia, sumber daya alam, iptek, dana, informasi, dan kelembagaan melalui diversifikasi, intensifikasi, ekstensifikasi, dan rehabilitasi. Peran sektor pertanian, kehutanan dan perikanan yang meliputi pertanian pangan dan hortikultura, perkebunan, peternakan dan perikanan, dalam perekonomian Aceh Tenggara selama ini masih dominan. Namun, produktivitas sektor pertanian, kehutanan dan perikanan tercatat paling rendah dibandingkan sektor lainnya. Kondisi ini disebabkan faktor-faktor antara lain penguasaan lahan pertanian yang terlalu sempit, kurangnya penguasaan informasi pasar dan iptek pertanian, rendahnya nilai tambah produk pertanian dan adanya periode menunggu hasil usaha pertanian. Disamping itu produksi pertanian belum mampu menjamin kelangsungan dan kualitas yang baik, serta adanya kebijakan impor komoditas tertentu.

Kabupaten Aceh Tenggara mempunyai potensi wilayah, kondisi geografis, maupun potensi khas lain yang berbeda dengan kabupaten atau kota lainnya, oleh karena itu penyusunan kebijakan pembangunan daerah tidak dapat serta merta mengadopsi kebijakan nasional, provinsi maupun daerah lain yang maju. Kebijakan yang diambil harus sesuai dengan masalah, kebutuhan dan potensi daerah. Pertanyaanya kemudian adalah bagaimanakah peran pertanian, kehutanan dan perikanan sebagai sektor basis dalam perekonomian Kabupaten Aceh Tenggara dan bagaimanakah pertumbuhan dan perkembangan pertanian, kehutanan dan perikanan di Kabupaten Aceh Tenggara? Hal tersebut berguna untuk mengetahui kecenderungan perubahan sektor pertanian, kehutanan dan perikanan kabupaten Aceh Tenggara serta untuk mengetahui pertumbuhan dan perkembangan sektor pertanian, kehutanan dan perikanan dalam perekonomian Kabupaten Aceh Tenggara. Sebagai pertimbangan bagi Pemerintah Daerah dalam menentukan kebijakan dibidang pertanian, perikanan dan kehutanan dan sebagai sumber serta bahan referensi bagi penulis lain untuk menggali peran pertanian, perikanan dan kehutanan di Aceh Tenggara.

\section{Kontribusi Sektor Pertanian Sebagai Penopang Perekomian Nasional dan Daerah.}

Sektor pertanian merupakan sektor yang strategis dan berperan penting dalam pembangunan perekonomian nasional maupun daerah dan merupakan penopang utama kelangsungan hidup masyarakat Indonesia, terutama dalam sumbangan terhadap PDB, penyedia lapangan kerja dan penyediaan pangan dalam negeri. (Latumaerissa, 2015).

Pertanian adalah kegiatan pemanfaatan sumber daya hayati yang dilakukan manusia mengahasilkan bahan pangan, bahan baku industri, atau sumber energi, serta untuk mengelola lingkungan hidup. Oleh karenanya sektor pertanian adalah sektor yang paling dasar dalam perekonomian yang merupakan penopang kehidupan 
produksi sektor-sektor lainnya seperti subsektor perikanan, subsektor perkebunan, subsektor perternakan. (Putong, 2005). Pembangunan di bidang pertanian adalah suatu hal yang tidak dapat ditawar-tawar lagi, karena sebagian besar rakyat Indonesia mengkonsumsi beras dan bekerja di sektor pertanian. (Subandi, 2009). Sedangkan peranan penting dari sektor pertanian itu sendiri adalah dalam membentuk penyediaan kesempatan kerja dan berkontribusi terhadap pembentukan produk domestik bruto dan ekspor. (Tambunan, 2006).

Menurut analisis Klasik dari Kuznets adalah pertanian di negara-negara sedang berkembang merupakan suatu sektor ekonomi yang sangat potensial, terdapat 4 bentuk kontribusinya terhadap pertumbuhan dan pembangunan ekonomi yaitu (Tambunan, 2006). Pertama,ekspansi dari sektor-sektor ekonomi non pertanian sangat tergantung pada produk-produk dari sektor pertanian, bukan saja untuk kelangsungan pertumbuhan suplai makanan tetapi juga untuk penyediaan bahan baku untuk keperluan kegiatan produksi di sektor-sektor non pertanian tersebut. Kedua, karena kuatnya bias agraris dari ekonomi selama tahap-tahap awal pembangunan, maka populasi di sektor pertanian daerah pedesaan membentuk suatu bagian yang sangat besar dari pasar permintaan domestik terhadap produk-produk dari industri dan sektor-sektor lain di dalam negeri, baik untuk barang-barang produsen maupun barang-barang konsumen, kuznets menyebutnya kontribusi pasar. Ketiga, karena relatif pentingnya pertanian bisa dilihat dari sumbangan out-putnya terhadap pembentukan produk domestik bruto dan andilnya terhadap penyerapan tenaga kerja tanpa bisa dihindari menurun dengan pertumbuhan atau semakin tingginya tingkat pembangunan ekonomi. Keempat, sektor pertanian mampu berperan sebagai salah satu sumber penting bagi surplus neraca perdagangan atau neraca pembayaran, baik lewat ekspor hasil-hasil pertanian atau peningkatan produksi komoditi-komiditi pertanian menggantikan impor.

\section{Pengertian Kehutanan}

Kehutanan adalah suatu praktik untuk membuat, mengelola, menggunakan dan melestarikan hutan untuk kepentingan manusia. Menurut Undang-Undang Republik Indonesia No 41 Tahun 1999 tentang kehutanan yaitu kehutanan adalah sistem pengurusan yang bersangkut paut dengan hutan, kawasan hutan, dan hasil hutan yang di selenggarakan secara terpadu. (go.id, 1999) Menurut Simon, perkembangan teori pengelolaan hutan dapat di kelompokan ke dalam dua kategori yaitu, Pertama Kehutanan Konvensional, Pengelolaan hutan yang termasuk ke dalam kehutanan konvensional adalah penambangan kayu dan perkebunan kayu. Kedua Kehutanan Modern, Kehutanan sosial adalah pengelolaan hutan sebagai sumber daya dan pengelolaan hutan sebagai ekosistem.

\section{Pengelolaan, Penangkapan dan Pembudidayaan Perikanan}

Di Indonesia Menurut UU RI N0. 31/2004 sebagaimana telah di ubah dengan UU RI NO. 45/2009, kegiatan yang termasuk dalam perikanan dimulai dari praproduksi, produksi, pengolahan sampai dengan pemasaran, yang dilaksanakan dalam suatu sistem bisnis perikanan atau yang disebut dengan agribisnis. (org, 2019). Perikanan adalah kegiatan manusia yang berhubungan dengan pengelolaan 
dengan pengelolaan dan pemanfaatan sumberdaya hayati perairan. umumnya perikanan dimaksudkan untuk kepentingan penyediaan pangan bagi manusia. Pengelolaan sumberdaya ikan adalah semua upaya termasuk proses yang terintegrasi dalam pengumpulan, alokasi sumberdaya ikan, serta penegakan hukum dari undangundang dibidang perikanan Penangkapan ikan merupakan kegiatan yang bertujuan untuk memperoleh ikan di perairan yang tidak dalam keadaan dibudidayakan dengan alat atau cara apapun termasuk kegiatan yang menggunakan kapal penangkapan ikan untuk memuat, mengangkut, menyimpan atau mengawetkannya. Pembudidayaan ikan adalah kegiatan untuk memelihara, membesarkan dan atau membiakkan ikan, memanen hasilnya dalam lingkungan yang terkontrol.

\section{METODE PENELITIAN}

Penelitian ini dilakukan di Kabupaten Aceh Tenggara yang dilakukan secara sengaja (purposive) karena Kabupaten Aceh Tenggara salah satu daerah yang unggul diberbagai bidang, Penelitian ini dilakukan pada Bulan Mei 2019 sampai dengan September 2019. Data yang digunakan dalam penelitian ini adalah data sekunder yang bersumber dari Badan Pusat Statistik (BPS) Kabupaten Aceh Tenggara dan BPS Provinsi Aceh. Data yang tercakup dalam penelitian ini adalah data PDRB Provinsi Aceh, data Kabupaten Aceh Tenggara dari Tahun 2014 sampai Tahun 2018 atas harga yang berlaku dan data pendukung lainya.

\section{Analisis Data}

Dengan mengunakan model Analisis LQ. Menurut Kadariah (1985), metode Analisis Location Quotient (LQ) bertujuan untuk mengidentifikasi suatu komoditi yang ada pada suatu wilayah apakah termasuk kedalam suatu basis atau non basis. Dengan kata lain, nilai LQ akan memberikan indikasi kemampuan suatu daerah dalam menghasilkan suatu komoditi, apakah mempunyai potensi untuk menyuplai daerah lain, mendatangkan dari daerah lain, atau dalam keadaan seimbang.

Rumusan LQ menurut Yantu (2012), adalah sebagai berikut:

$$
L Q s p=\frac{P D R B s p m}{T P D R B m}
$$

Keterangan:

LQ = Koefisien Location Quotient (LQ) Sektor Pertanian, Kehutanan dan Perikanan Aceh Tenggara

PDRBspm $=$ PDRB sektor Pertanian, Kehutanan dan Perikanan Aceh Tenggara (Rp.).

TPDRBm $=$ Total PDRB Aceh Tenggara (Rp.)

Jika LQ $\geq 1$ berarti tingkat spesialisasi Sektor Pertanian, Kehutanan dan Perikanan di Aceh Tenggara lebih besar dari pada sektor yang sama di Provinsi Aceh, sehingga Sektor Pertanian, Kehutanan dan Perikanan merupakan sektor basis. Jika LQ $<1$ berarti tingkat spesialisasi Sektor Pertanian, Kehutanan dan Perikanan 
di Kabupaten Aceh Tenggara lebih kecil dari pada sektor yang sama di Provinsi Aceh, sehingga sektor tersebut bukan sektor basis. Alat analisis Location Quotient mempunyai sejumlah keunggulan dan kelemahan (Bappenas, 2005). Keunggulan metode Location Quatient ini antara lain adalah memperhitungkan ekspor langsung dan ekspor tidak langsung. Metode ini sederhana dan tidak mahal dan dapat diterapkan pada data historis untuk mengetahui trend. Kelemahan metode LQ adalah bahwa metode ini berasumsi bahwa pola permintaan di setiap daerah identik dengan pola permintaan nasional dan bahwa produktivitas tiap pekerja di setiap sektor regional sama dengan produktivitas tiap pekerja dalam industri-industri nasional/regional di tingkat atasnya, dan asumsi bahwa tingkat ekspor tergantung pada tingkat disagregasi.

\section{HASIL DAN PEMBAHASAN}

Kabupaten Aceh Tenggara adalah salah satu kabupaten di Provinsi Aceh , Indonesia. Ibu kota kabupaten ini terletak di Kutacane. Kabupaten ini memiliki luas wilayah $4.231 \mathrm{~km}^{2}$ dan berpenduduk sebanyak 221.684 jiwa (2019). Kabupaten ini merupakan hasil pemekaran dari Kabupaten Aceh Tengah tanggal 26 Juni 1974. Secara geografis Kabupaten Aceh Tenggara terletak pada Koordinat: $4^{\circ} 22^{\prime} 14,42^{\prime \prime}$ $4^{\circ} 42^{\prime} 40,8^{\prime \prime} \mathrm{LU}$ dan $96^{\circ} 15 ' 23,6^{\prime \prime}-96^{\circ} 22^{\prime} 10,76^{\prime \prime}$ BT, dan secara administratif memiliki batas-batas sebagai berikut: Sebelah utara berbatasan dengan wilayah Kabupaten Gayo Lues. Sebelah timur berbatasan dengan Provinsi Sumatra Utara. Sebelah selatan berbatasan dengan wilayah Kabupaten Aceh Selatan dan Subulussalam Sebelah barat berbatasan dengan wilayah Kabupaten Aceh Selatan.

Tabel 1. Pejabat Pemerintahan dari masa ke masa.

\begin{tabular}{|c|l|c|c||}
\hline \hline No. & Nama Bupati & Awal Jabatan & Masa Jabatan \\
\hline \hline 1. & Lettu. H. Syahadat & 1975 & 1981 \\
\hline \hline 2. & T. Djohan Syahbudin, SH. & 1981 & 1986 \\
\hline \hline 3. & Drs. H. T. Iskandar & 1986 & 1991 \\
\hline \hline 4. & Drs. H. Syahbuddin BP & 1991 & 2001 \\
\hline \hline 5. & H.Armen Desky & 2001 & 2006 \\
\hline \hline 6. & Ir. H. Hasanuddin Broeh, MM. & 2006 & 2017 \\
\hline \hline 7. & Drs. Raidin Pinim,M.Ap & 2 Oktober 2017 & 2022 \\
\hline
\end{tabular}

Berdasarkan Permendagri No.137 tahun 2017, Kabupaten Aceh Tenggara terdiri dari 16 Kecamatan, yaitu Kecamatan Babul Makmur, Kecamatan Babul Rahmah, Kecamatan Babussalam, Kecamatan Badar, Kecamatan Bambel, Kecamatan Bukit Tusam. Kecamatan Darul Hasanah, Kecamatan Deleng Phokisen, Kecamatan Ketambe, Kecamatan Lawe Alas, Kecamatan Lawe Bulan, Kecamatan Lawe Sigala-gala, Kecamatan Lawe Sumur, Kecamatan Leuser, Kecamatan Semadam, Kecamatan Tanah Alas. 


\section{Tinjauan Ekonomi Kabupaten Aceh Tenggara}

Nilai PDRB Kabupaten Aceh Tenggara atas dasar harga berlaku pada tahun 2018 mencapai 4,56 triliun rupiah. Secara nominal, nilai PDRB ini mengalami kenaikan sebesar 322,41 milyar rupiah dibandingkan dengan tahun 2017 yang mencapai 4,24 triliun rupiah. Naiknya nilai PDRB ini dipengaruhi oleh meningkatnya produksi dan adanya inflasi. Berdasarkan harga konstan 2010, angka PDRB juga mengalami kenaikan, dari 3,19 triliun rupiah pada tahun 2017 menjadi 3,30 triliun rupiah pada tahun 2018. Hal ini menunjukkan selama tahun 2018 Kabupaten AcehTenggara mengalami pertumbuhan ekonomi sekitar 3,46 persen, melambat dibandingkan tahun sebelumnya. Perlambatan pertumbuhan ini disebabkan oleh penurunan produksi padi dan jagung yang merupakan produk dengan penyumbang ekonomi terbesar di Kabupaten AcehTenggara.

\section{Struktur Ekonomi Kabupaten Aceh Tenggara}

Besarnya peranan berbagai lapangan usaha ekonomi dalam memproduksi barang dan jasa sangat menentukan struktur ekonomi suatu daerah.Struktur ekonomi yang terbentuk dari nilai tambah yang diciptakan oleh setiap lapangan usaha menggambarkan seberapa besar ketergantungan suatu daerah terhadap kemampuan berproduksi dari setiap lapangan usaha. Selama lima tahun terakhir (2014 2018) struktur perekonomian Kabupaten Aceh Tenggara didominasi oleh 3 (tiga) kategori lapangan usaha, diantaranya: Pertanian, Kehutanan, dan Perikanan; Perdagangan Besar dan Eceran, Reparasi Mobil, dan Sepeda Motor; dan Administrasi Pemerintahan, Pertahanan dan Jaminan Sosial Wajib. Hal ini dapat dilihat dari peranan masing-masing lapangan usaha terhadap pembentukan PDRB Kabupaten Aceh Tenggara. Peranan terbesar dalam pembentukan PDRB Kabupaten Aceh Tenggara pada tahun 2018 dihasilkan oleh lapangan usaha Pertanian, Kehutanan dan Perikanan, yaitu mencapai 40,66 persen (angka ini menurun dari 43,12 persen di tahun 2014).

Selanjutnya lapangan usaha Perdagangan Besar dan Eceran, Reparasi Mobil, dan Sepeda Motor sebesar 14,34 persen ( naik dari 12,99 persen di tahun 2014), disusul oleh lapangan usaha Administrasi Pemerintahan, Pertahanan dan Jaminan Sosial Wajib sebesar 13,56 persen (naik dari 12,62 persen di tahun 2014). Di antara ketiga lapangan usaha tersebut, Perdagangan Besar dan Eceran, Reparasi Mobil, dan Sepeda Motor; dan Administrasi Pemerintahan, Pertahanan dan Jaminan Sosial Wajibadalah kategori yang mengalami peningkatan peranan. Sebaliknya, Pertanian, Kehutanan, dan Perikanan peranannya berangsur-angsur menurun. Sementara itu, peranan lapangan usaha lainnya, masing-masing kurang dari 10 persen. Salah satu penyebab menurunnya peranan Pertanian, Kehutanan, dan Perikanan adalah lambatnya kenaikan harga produk lapangan usaha tersebut dibandingkan produk lain. Penurunan luas lahan pertanian dan kualitas tanaman perkebunan juga menjadi penyebab turunnya peranan lapangan usaha Pertanian, Kehutanan, dan Perikanan. 
Tabel 2. Distribusi Persentase Produk Domestik Regional Bruto Kabupaten Aceh Tenggara Atas Dasar Harga Berlaku Menurut Lapangan Usaha Tahun

$2014-2018$.

\begin{tabular}{|c|c|c|c|c|c|c|}
\hline \multirow{2}{*}{\multicolumn{2}{|c|}{$\begin{array}{c}\text { Lapangan Usaha/Industry } \\
\text { (1) }\end{array}$}} & \multirow{3}{*}{$\begin{array}{c}\mathbf{2 0 1 4} \\
\mathbf{( 2 )} \\
43.15\end{array}$} & \multirow{3}{*}{\begin{tabular}{c|}
$\mathbf{2 0 1 5}$ \\
$\mathbf{( 3 )}$ \\
43.19
\end{tabular}} & \multirow{3}{*}{$\begin{array}{c}\frac{2016}{(4)} \\
42.55\end{array}$} & \multirow{3}{*}{\begin{tabular}{c|}
$\mathbf{2 0 1 7}$ \\
$\mathbf{( 5 )}$ \\
41.76
\end{tabular}} & \multirow{3}{*}{\begin{tabular}{c|}
$\mathbf{2 0 1 8}$ \\
$\mathbf{( 6 )}$ \\
40.50
\end{tabular}} \\
\hline & & & & & & \\
\hline 1 & $\begin{array}{l}\text { Pertanian, Kehutanan, dan } \\
\text { Perikanan }\end{array}$ & & & & & \\
\hline 2 & $\begin{array}{l}\text { Pertambangan dan } \\
\text { Penggalian }\end{array}$ & 1.15 & 1.15 & 1.06 & 1.03 & 0.96 \\
\hline 3 & $\begin{array}{l}\text { Industri Pengolahan/ } \\
\text { Manufacturing }\end{array}$ & 1.18 & 1.21 & 1.26 & 1.31 & 1.39 \\
\hline 4 & $\begin{array}{l}\text { Pengadaan Listrik dan } \\
\text { GasHectricity and Gas }\end{array}$ & 0.12 & 0.09 & 0.10 & 0.10 & 0.10 \\
\hline 5 & $\begin{array}{l}\text { Pengadaan Air, } \\
\text { Pengelolaan Sampah, } \\
\text { Limbah dan Daur } \\
\text { Ulang/Water supply, } \\
\text { Sewerage, Waste } \\
\text { Management and } \\
\text { Remediation Activities }\end{array}$ & 0.02 & 0.02 & 0.02 & 0.02 & 0.02 \\
\hline 6 & Konstruksi/Construction & 5.36 & 6.12 & 5.80 & 6.13 & 6.06 \\
\hline 7 & $\begin{array}{l}\text { Perdagangan Besar dan } \\
\text { Eceran; Reparasi Mobil } \\
\text { dan Sepeda } \\
\text { Motor/Wholesale and } \\
\text { Retail Trade; Repair of } \\
\text { Motor Vehicles and } \\
\text { Motorcycles }\end{array}$ & 13.85 & 12.99 & 13.22 & 13.42 & 13.81 \\
\hline 8 & $\begin{array}{l}\text { Transportasi dan } \\
\text { Pergudangan } \\
\text { Transportation }\end{array}$ & 5.15 & 4.76 & 4.60 & 4.46 & 4.44 \\
\hline 9 & $\begin{array}{l}\text { Penyediaan Akomodasi } \\
\text { dan Makan Minum }\end{array}$ & 0.50 . & 0.60 & 0.63 & 0.64 & 0.67 \\
\hline 10 & $\begin{array}{l}\text { Informasi dan } \\
\text { Komunikasi/Information }\end{array}$ & 2.17 & 1.99 & 1.95 & 1.85 & 1.76 \\
\hline 11 & $\begin{array}{l}\text { Jasa Keuangan dan } \\
\text { Asuransi }\end{array}$ & 3.18 & 3.08 & 3.06 & 2.97 & 3.12 \\
\hline 12 & $\begin{array}{l}\text { Real Estat/Real Estate } \\
\text { Activities }\end{array}$ & 3.91 & 4.02 & 4.10 & 4.02 & 4.03 \\
\hline 13 & $\begin{array}{l}\text { Jasa Perusahaan/ Business } \\
\text { Activities }\end{array}$ & 0.57 & 0.44 & 0.42 & 0.41 & 0,40 \\
\hline 14 & $\begin{array}{l}\text { Administrasi } \\
\text { Pemerintahan, } \\
\text { Pertahanan dan Jaminan }\end{array}$ & 11.72 & 12.62 & 12.95 & 13.14 & 13.23 \\
\hline
\end{tabular}




\begin{tabular}{|c|l|c|c|c|c|c|}
\hline & $\begin{array}{l}\text { Sosial Wajib/Public } \\
\text { Administration and } \\
\text { Defence; Compulsory } \\
\text { Social Security }\end{array}$ & & & & & \\
\hline 15 & $\begin{array}{l}\text { JasaPendidikan } \\
\text { /Education }\end{array}$ & 2.72 & 12.62 & 12.95 & 13.14 & 13.23 \\
\hline 16 & $\begin{array}{l}\text { Jasa Kesehatan dan } \\
\text { Kegiatan Sosial/Human }\end{array}$ & 3.35 & 3.27 & 3.31 & 3.38 & 3.70 \\
\hline 17 & $\begin{array}{l}\text { R,S,T,U Jasa } \\
\text { lainnya/Other Services } \\
\text { Activities }\end{array}$ & 1.81 & 1.87 & 1.91 & 1.93 & 1.92 \\
\hline
\end{tabular}

\section{Pertumbuhan Ekonomi Kabupaten Aceh Tenggara}

Pertumbuhan ekonomi merupakan salah satu indikator makro untuk melihat kinerja perekonomian secara riil di suatu wilayah. Laju pertumbuhan ekonomi dihitung berdasarkan perubahan PDRB atas dasar harga konstan tahun yang bersangkutan terhadap tahun sebelumnya. Pertumbuhan ekonomi dapat dipandang sebagai pertambahan jumlah barang dan jasa yang dihasilkan oleh semua lapangan usaha kegiatan ekonomi yang ada di suatu wilayah selama kurun waktu setahun. Berdasarkan harga konstan 2010, nilai PDRB Kabupaten Aceh Tenggara pada tahun 2018 meningkat. Peningkatan tersebut dipengaruhi oleh meningkatnya produksi di sebagian besar lapangan usaha dan tidak dipengaruhi oleh inflasi. Nilai PDRB Kabupaten Aceh Tenggara atas dasar harga konstan 2010 pada tahun 2018 mencapai 3,30 triliun rupiah. Angka tersebut naik dari 3,19 triliun rupiah pada tahun 2017. Hal tersebut menunjukkan bahwa selama tahun 2018 terjadi pertumbuhan ekonomi sebesar 3,46 persen, namun melambat dibandingkan pertumbuhan ekonomi tahun sebelumnya yang mencapai 4,65 persen. Pertumbuhan ekonomi selama 2018 diperlambat oleh adanya perlambatan signifikan pada produksi lapangan usaha Pertanian, Kehutanan dan Perikanan. Namun pertumbuhan tetap bertahan positif dikarenakan peningkatan produksi secaratota.l dari 17 lapangan usaha ekonomi yang ada, seluruhnya mengalami pertumbuhan yang positif. Sepuluh lapangan usaha mengalami pertumbuhan positif lebih besar atau sama dengan lima persen. Sedangkan tujuh lapangan usaha lainnya berturut- turut tercatat mengalami pertumbuhan positif namun lebih rendah, yaitu kurang dari lima persen. Pertumbuhan ekonomi tertinggi pada tahun 2018 dicapai oleh lapangan usaha Pengadaan Air, Pengelolaan Sampah, Limbah dan Daur Ulang yaitu sebesar 19,51 persen. Kemudian disusul oleh lapangan usaha Pengadaan Listrik dan Gas sebesar 10,63 persen, lapangan usaha Penyedia Akomodasi dan Makan Minum sebesar 10,35 persen, lapangan usaha Jasa Pendidikan sebesar 7,37 persen, lapangan usaha Industri Pengolahan sebesar 7,13 persen, lapangan usaha Pertambangan dan Penggalian sebesar 7,00 persen, lapangan usaha.Perdagangan Besar dan Eceran; Reparasi Mobil dan Sepeda Motor sebesar 6,00 persen, lapangan usaha Jasa Kesehatan dan Kegiatan Sosial sebesar 5,63 persen, lapangan usaha Jasa Lainnya sebesar 5,16 persen dan lapanganusaha Konstruksi sebesar 5,05 persen. Sedangkan tujuh lapangan usaha yang mengalami pertumbuhan positif kurang dari lima persen adalah lapangan usaha Administrasi Pemerintahan, Pertahanan dan Jaminan Sosial Wajib sebesar 4,77 persen, lapangan usaha, 
Jasa Perusahaan sebesar 4,62 persen, lapangan usaha Informasi dan Komunikasi sebesar 3,82 persen, lapangan usaha Jasa Keuangan dan Asuransi sebesar 2,29 persen, lapangan usaha Transportasi dan Pergudangan sebesar 2,23 persen, dan lapangan usaha Pertanian, Kehutanan dan Perikanan sebesar 1,39 persen.

Tabel 3. Laju Pertumbuhan Produk Domestik Regional Bruto Atas Dasar Harga Konstan 2010 Kabupaten Aceh Tenggara Menurut Lapangan Usaha (persen), 2014-2018.

\begin{tabular}{|c|c|c|c|c|c|c|}
\hline \multicolumn{2}{|c|}{ Lapangan Usaha/Industry } & 2014 & 2015 & 2016 & 2017 & 2018 \\
\hline \multicolumn{2}{|c|}{ (1) } & $(2)$ & (3) & (4) & (5) & (6) \\
\hline 1 & $\begin{array}{l}\text { Pertanian, Kehutanan, dan } \\
\text { Perikanan }\end{array}$ & 1.48 & 4.42 & 3.34 & 2.49 & 1.39 \\
\hline 2 & $\begin{array}{l}\text { Pertambangan dan } \\
\text { Penggalian/Mining and }\end{array}$ & 8.79 & 2.15 & 5.07 & 0.47 & 7.00 \\
\hline 3 & $\begin{array}{l}\text { Industri } \\
\text { Pengolahan/Manufacturing }\end{array}$ & 7.90 & 5.93 & 7.47 & 8.88 & 7.13 \\
\hline 4 & $\begin{array}{l}\text { Pengadaan Listrik dan GasE } \\
\text { lectricity and Gas }\end{array}$ & 5.37 & 6.99 & 10.38 & 6.90 & 10.63 \\
\hline 5 & $\begin{array}{l}\text { Pengadaan Air, } \\
\text { Pengelolaan Sampah, } \\
\text { Limbah dan Daur } \\
\text { Ulang/Water supply, } \\
\text { Sewerage, Waste } \\
\text { Management and } \\
\text { RemediationActivities } \\
\end{array}$ & 3.14 & 3.97 & 7.03 & 5.66 & 19.51 \\
\hline 6 & Konstruksi/Construction & 12.39 & 0.01 & 9.95 & 4.12 & 5.05 \\
\hline 7 & $\begin{array}{l}\text { Perdagangan Besar dan } \\
\text { Eceran; Reparasi Mobil dan } \\
\text { Sepeda Motor/Wholesale and } \\
\text { Retail Trade; Repair of } \\
\text { Motor Vehicles and } \\
\text { Motorcycles }\end{array}$ & 2.84 & 4.96 & 4.58 & 6.88 & 6.00 \\
\hline 8 & $\begin{array}{l}\text { Transportasi dan } \\
\text { Pergudangan/Transportation }\end{array}$ & 3.82 & 3.60 & 0.41 & 8.25 & 2.23 \\
\hline 9 & $\begin{array}{l}\text { Penyediaan Akomodasi dan } \\
\text { Makan Minum }\end{array}$ & 4.72 & 6.14 & 6.87 & 7.35 & 10.35 \\
\hline 10 & $\begin{array}{l}\text { Informasi dan } \\
\text { Komunikasi/Information }\end{array}$ & 6.33 & 3.90 & 1.58 & 3.36 & 3.82 \\
\hline 11 & Jasa Keuangan dan Asuransi & 2.62 & 1.01 & 2.14 & 7.65 & 2.29 \\
\hline 12 & $\begin{array}{l}\text { Real Estat/Real Estate } \\
\text { Activities }\end{array}$ & 6.98 & 4.60 & 4.37 & 4.18 & 2.81 \\
\hline 13 & $\begin{array}{l}\text { Jasa Perusahaan/ Business } \\
\text { Activities }\end{array}$ & 1.59 & 1.33 & 1.46 & 3.16 & 4.62 \\
\hline 14 & $\begin{array}{l}\text { Administrasi Pemerintahan, } \\
\text { Pertahanan dan Jaminan }\end{array}$ & 8.61 & 4.50 & 5.21 & 5.00 & 4.77 \\
\hline
\end{tabular}




\begin{tabular}{|c|l|l|l|l|l|l|}
\hline & $\begin{array}{l}\text { Sosial Wajib/Public } \\
\text { Administration } \\
\text { and Defence; Compulsory } \\
\text { Social Security }\end{array}$ & & & & & \\
\hline 15 & JasaPendidikan/Education & 4.40 & 4.85 & 4.07 & 5.66 & 7.37 \\
\hline 16 & $\begin{array}{l}\text { Jasa Kesehatan dan Kegiatan } \\
\text { Sosial/Human }\end{array}$ & 4.74 & 4.45 & 7.73 & 14.99 & 5.63 \\
\hline 17 & $\begin{array}{l}\text { R,S,T,U Jasa lainnya/Other } \\
\text { Services Activities }\end{array}$ & 4.35 & 3.94 & 5.03 & 4.61 & 5.16 \\
\hline & $\begin{array}{l}\text { Produk Domestik Regional } \\
\text { Brutø Gross Regional }\end{array}$ & $\mathbf{3 . 8 4}$ & $\mathbf{4 . 0 3}$ & $\mathbf{4 . 2 4}$ & $\mathbf{4 . 6 5}$ & $\mathbf{3 . 4 6}$ \\
\hline
\end{tabular}

\section{PDRB Per Kapita}

Salah satu indikator tingkat kemakmuran penduduk di suatu daerah dapat dilihat dari nilai PDRB per kapita, yang merupakan hasil bagi antara nilai tambah yang dihasilkan oleh seluruh kegiatan ekonomi dengan jumlah penduduk. Oleh karena itu, besar kecilnya jumlah penduduk akan mempengaruhi nilai PDRB per kapita, sedangkan besar kecilnya nilai PDRB sangat tergantung pada potensi sumber daya alam dan faktor-faktor produksi yang terdapat di daerah tersebut. PDRB per kapita atas dasar harga berlaku menunjukkan nilai PDRB per kepala atau per satu orang penduduk. Nilai PDRB per kapita Kabupaten Aceh Tenggara atas dasar harga berlaku sejak tahun 2014 hingga 2018 senantiasa mengalami kenaikan. Pada tahun 2014 PDRB per kapita tercatat sebesar 16,88 juta rupiah.

Secara nominal terus mengalami kenaikan hingga tahun 2018 mencapai 21,46 juta rupiah (lihat tabel 3.3). Kenaikan angka PDRB per kapita yang cukup tinggi ini disebabkan masih dipengaruhi oleh faktor inflasi. Pertumbuhan PDRB per kapita Kabupaten Aceh Tenggara selama lima tahun terakhir terus mengalami peningkatan. Dimana pada tahun 2018 tumbuh 1,54 persen yang merupakan pertumbuhan terendah selama lima tahun terakhir. Sedangkan pertumbuhan tertinggi terjadi pada tahun 2017 sebesar 2,63 persen.

Tabel 4. Produk Domestik Regional Bruto dan PDRB Perkapita Kabupaten Aceh Tenggara 2014-2018.

\begin{tabular}{|c|c|c|c|c|c|}
\hline $\begin{array}{l}\text { Uraian / } \\
\text { Description }\end{array}$ & 2014 & 2015 & $2016^{r}$ & $2017^{*}$ & $2018 * *$ \\
\hline \multicolumn{6}{|c|}{ Nilai PDRB/GRDP (Milliar Rupiah/Billion rupiahs) } \\
\hline $\begin{array}{l}\text {-ADHB/at } \\
\text { current price }\end{array}$ & $3,313.78$ & $3,567.14$ & $3,883.18$ & $4,235.56$ & $4,557.97$ \\
\hline $\begin{array}{l}\text {-ADHK/at } 2010 \\
\text { Constant Price }\end{array}$ & $2,807.99$ & $2,921.13$ & $3,044.88$ & $3,186.36$ & $3,296.48$ \\
\hline \multicolumn{6}{|c|}{ PDRB Per Kapita/PerCapitaGRDP(Ribu Rupiah/Thousand rupiah) } \\
\hline $\begin{array}{l}\mathrm{ADHB} / \text { at } \\
\text { current price }\end{array}$ & $16,885.58$ & $17,834.46$ & $18,991.65$ & $20,316.30$ & $21,457.67$ \\
\hline
\end{tabular}




\begin{tabular}{|c|c|c|c|c|c|}
\hline $\begin{array}{l}\text {-ADHK/at } 2010 \\
\text { Constant Price }\end{array}$ & $14,308.31$ & $14,604.63$ & $14,891.72$ & $15,283.70$ & $15,518.91$ \\
\hline \begin{tabular}{|l|}
-Pertumbuhan \\
PDRB per Kapita \\
ADHK \\
2010/Growth of \\
Per Capita GRDP \\
at 2010 Constant \\
Price \\
\end{tabular} & 1.60 & 2.07 & 1.97 & 2.63 & 1.54 \\
\hline \begin{tabular}{|l|} 
Jumlah \\
Penduduk (ribu \\
orang)/ \\
Population \\
(Thousand \\
People) \\
\end{tabular} & 196,249 & 200,014 & 204,468 & 208,481 & 212,417 \\
\hline $\begin{array}{l}\text { Pertumbuhan } \\
\text { Jumlah } \\
\text { Penduduk } \\
\text { (Persen)/ } \\
\text { Population } \\
\text { Growth } \\
\text { (Percent) }\end{array}$ & 2.21 & 1.92 & 2.23 & 1.96 & 1.89 \\
\hline
\end{tabular}

\section{Peran Pertanian, Kehutanan, dan Perikanan Dalam Perekonomian Aceh Tenggara}

Kategori ini mencakup Subkategori Pertanian, Kehutanan, dan Perikanan, Subkategori kehutanan dan Penebangan Kayu, dan Subkategori Perikanan. Industri ini masih menjadi tumpuan dan harapan dalam penyerapan tenaga kerja. Kontribusi kategori Pertanian, Kehutanan, dan Perikanan terhadap PDRB pada tahun 2018 atas dasar harga berlaku mencapai 1,85 triliun rupiah atau sebesar 40,66 persen. Subkategori usaha Pertanian, Peternakan, Perburuan, dan Jasa Pertanian merupakan contributor terbesar dalam menciptakan nilai tambah lapangan usaha Pertanian, Kehutanan,dan Perikanan, mencapai 85,62 persen. Sementara itu, kontribusi kedua subkategori yang lain terhadap kategori Pertanian, Kehutanan, dan Perikananrelatif kecil. Kontribusi subkategori Kehutanan dan Penebangan Kayu sebesar 50,92 miliar rupiah atau 2,75 persen dan subkategori Perikanan lebih tinggi, yaitu 215,51 miliar rupiah atau 11,63 persen. Pertumbuhan ekonomi pada kategori Pertanian, Kehutanan, dan Perikanan berfluktuasi selama lima tahun terakhir. Fluktuasi tersebut terjadi karena fluktuasi yang terjadi pada subkategori Pertanian, Peternakan, Perburuan, dan Jasa Pertanian yang memiliki peranan besar pada nilai total kategori ini. Pada tahun 2018, kategori ini tumbuh sebesar1,39 persen. Angka ini lebih rendah dibandingkan dengan tahun 2017 yang sebesar 2,49 persen. Sepanjang tahun 2018, produksi tanaman jagung dan padi yang merupakan tanaman penyumbang perekonomian terbesar mengalami penurunan 
signifikan. Selain itu, kondisi tanah yang tidak stabil menyebakan pengumpul hasil hutan seperti madu mengurangi aktivitasnya dikarenakan berbahaya.

Tabel 5. Peranan Subkategori terhadap Nilai Tambah Kategori Pertanian, Peternakan, Perburuan, dan Jasa Pertanian di Kabupaten Aceh Tenggara (Persen),2014-2018.

\begin{tabular}{|l|c|c|c|c|c|}
\hline Lapangan Usaha/Industry & $\mathbf{2 0 1 4}$ & $\mathbf{2 0 1 5}$ & $\mathbf{2 0 1 6 r}$ & $\mathbf{2 0 1 7} *$ & $\mathbf{2 0 1 8}^{* *}$ \\
\hline \multicolumn{1}{|c|}{$(1)$} & $(2)$ & -3 & -4 & -5 & -6 \\
\hline $\begin{array}{l}\text { Pertanian, Peternakan, } \\
\text { Perburuan dan Jasa Services }\end{array}$ & 85.21 & 85.24 & 85.44 & 85.67 & 85.62 \\
\hline $\begin{array}{l}\text { Kehutanan dan Penebangan } \\
\text { Kayu/Forestry and Logging }\end{array}$ & 3.15 & 2.98 & 2.9 & 2.77 & 2.75 \\
\hline Perikanan/Fishery & 11.64 & 11.79 & 11.65 & 11.56 & 11.63 \\
\hline $\begin{array}{l}\text { Pertanian, Kehutanan,dan } \\
\text { Perikanan/Agriculture, }\end{array}$ & $\mathbf{1 0 0 , 0 0}$ & $\mathbf{1 0 0 , 0 0}$ & $\mathbf{1 0 0 , 0 0}$ & $\mathbf{1 0 0 , 0 0}$ & $\mathbf{1 0 0 , 0 0}$ \\
\hline
\end{tabular}

Tabel 6. Produk Domestik Regional Bruto Kabupaten Aceh Tenggara Atas Dasar Harga Konstan 2010 Menurut Lapangan Usaha (Juta Rupiah), 2014-2018.

\begin{tabular}{|c|c|c|c|c|c|c|}
\hline $\begin{array}{l}\text { Kategori/ } \\
\text { Category }\end{array}$ & $\begin{array}{l}\text { Lapangan } \\
\text { Usaha/ } \\
\text { Industry }\end{array}$ & 2014 & 2015 & $2016 r$ & 2017* & $2018 * *$ \\
\hline 1 & 2 & 3 & -4 & 5 & 6 & 7 \\
\hline $\begin{array}{ll}\text { A. } & \text { Pertanian, } \\
\text { Kehutanan, dan } \\
\text { Perikanan/ } \\
\text { Agriculture }\end{array}$ & & $1,208,431.08$ & $1,261,805.47$ & $1,303,960.11$ & $1,336,378.75$ & $1,354,941.02$ \\
\hline & $\begin{array}{l}\text { 1. Pertanian, } \\
\text { Peternakan, } \\
\text { Perburuan } \\
\text { dan Jasa } \\
\text { Pertanian/ } \\
\text { Agriculture, } \\
\text { Livestock, } \\
\text { Hunting and } \\
\text { Agriculture } \\
\text { Services }\end{array}$ & $1,003,048.95$ & $1,048,515.12$ & $1,085,253.24$ & $1,112,377.79$ & $1,125,161.33$ \\
\hline & $\begin{array}{l}\text { 2. Kehutanan } \\
\text { dan } \\
\text { Penebangan } \\
\text { Kayu/Forestr } \\
\text { y and }\end{array}$ & $44,286.98$ & $44,720.99$ & $45,009.63$ & $45,010.10$ & $44,919.10$ \\
\hline & $\begin{array}{l}\text { 3. Perikanan/ } \\
\text { Fishery }\end{array}$ & $161,095.15$ & $168,569.36$ & $173,697.24$ & $178,990.87$ & $184,860.59$ \\
\hline $\begin{array}{|ll|}\text { B. } & \text { Pertambangan } \\
& \text { dan Penggalian / } \\
& \text { Mining } \\
\end{array}$ & & $33,726.38$ & $33,001.26$ & $34,675.31$ & $34,839.00$ & $37,277.73$ \\
\hline 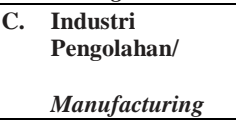 & & $32,822.36$ & $34,769.97$ & $37,366.46$ & $40,685.77$ & $43,587.44$ \\
\hline $\begin{array}{ll}\text { D. } & \text { Pengadaan } \\
& \text { Listrik dan } \\
\text { Gas/Electricity \& } \\
\text { Gas }\end{array}$ & & $3,547.39$ & $3,795.49$ & $4,189.55$ & $4,478.50$ & $4,954.41$ \\
\hline E. $\begin{array}{l}\text { Pengadaan Air, } \\
\text { Pengelolaan }\end{array}$ & & 414.19 & 430.63 & 460.88 & 486.97 & 581.98 \\
\hline
\end{tabular}




\begin{tabular}{|c|c|c|c|c|c|c|}
\hline & $\begin{array}{l}\text { Sampah, Limbah } \\
\text { dan Management } \\
\text { \&Remediation } \\
\text { Activities }\end{array}$ & & & & & \\
\hline F. & $\begin{array}{l}\text { Konstruksi/ } \\
\text { Construction }\end{array}$ & $170,295.03$ & $170,279.41$ & $187,228.95$ & $194,951.85$ & $204,787.87$ \\
\hline . & $\begin{array}{l}\text { Perdagangan } \\
\text { Besar dan } \\
\text { Eceran; Reparasi } \\
\text { Mobil dan } \\
\text { Sepeda } \\
\text { Motor/Wholesale } \\
\text { \&Retail Trade; } \\
\text { Repair of Motor } \\
\text { Vehicle \& } \\
\text { Motorcycles } \\
\end{array}$ & $367,823.97$ & $386,064.76$ & $403,748.29$ & $431,512.11$ & $457,383.61$ \\
\hline H. & $\begin{array}{l}\text { Transportasi dan } \\
\text { Pergudangan// } \\
\text { Transportation }\end{array}$ & $139,187.07$ & $144,193.85$ & $144,783.50$ & $156,731.85$ & $160,225.20$ \\
\hline I. & $\begin{array}{l}\text { Penyediaan } \\
\text { Akomodasi dan } \\
\text { Makan Minum/ } \\
\end{array}$ & $16,620.45$ & $17,640.30$ & $18,852.13$ & $20,237.34$ & $22,331.48$ \\
\hline J. & $\begin{array}{l}\text { Informasi dan } \\
\text { Komunikasi/Infor } \\
\text { mation }\end{array}$ & $62,785.58$ & $65,234.21$ & $66,262.80$ & $68,489.08$ & $71,107.06$ \\
\hline K. & $\begin{array}{l}\text { Jasa Keuangan } \\
\text { dan Asuransi// } \\
\text { Financial } \\
\end{array}$ & $79,362.29$ & $80,162.60$ & $81,880.54$ & $88,145.59$ & $90,167.49$ \\
\hline L. & $\begin{array}{l}\text { Real Estat/Real } \\
\text { Estate Activities } \\
\end{array}$ & $110,215.28$ & $115,287.32$ & $120,328.88$ & $125,361.77$ & $128,890.10$ \\
\hline M. & $\begin{array}{l}\text { Jasa Perusahaan/ } \\
\text { Bussiness } \\
\text { Activities } \\
\end{array}$ & $14,216.52$ & $14,405.84$ & $14,616.19$ & $15,077.80$ & $15,773.98$ \\
\hline$N$. & $\begin{array}{l}\text { Administrasi } \\
\text { Pemerintahan, } \\
\text { Pertahanan dan } \\
\text { Jaminan Sosial } \\
\text { Wajib/Public } \\
\text { Administration \& } \\
\text { Defence; } \\
\text { Compulsory } \\
\text { Social Security }\end{array}$ & $345,701.50$ & $361,258.06$ & $380,063.43$ & $399,069.77$ & $418,116.21$ \\
\hline O. & $\begin{array}{l}\text { Jasa Pendidikan/ } \\
\text { Education }\end{array}$ & $75,718.71$ & $79,391.07$ & $82,623.55$ & $87,296.91$ & $93,730.70$ \\
\hline P. & $\begin{array}{l}\text { Jasa Kesehatan } \\
\text { dan Kegiatan } \\
\text { Sosial/ Human } \\
\end{array}$ & $96,144.79$ & $100,423.23$ & $108,187.16$ & $124,401.60$ & $131,403.88$ \\
\hline Q. & $\begin{array}{l}\text { Jasa } \\
\text { lainnya/Other } \\
\text { Service Activities }\end{array}$ & $50,979.75$ & $52,987.55$ & $55,652.18$ & $58,217.40$ & $61,221.01$ \\
\hline & $\begin{array}{l}\text { roduk Domestik } \\
\text { egional Bruto/ } \\
\text { ross Regional } \\
\text { Oomestic }\end{array}$ & $2,807,992.31$ & $2,921,131.03$ & $3,044,879.93$ & $3,186,362.08$ & $3,296,481.16$ \\
\hline
\end{tabular}

Tabel diatas menunjukan bahwa Sektor Pertanian, Kehutanan dan Perikanan, merupakan sektor basis dalam perekonomian Kabupaen Aceh Tenggara, dengan nilai LQ $>1$. Artinya, Sektor Pertanian, Kehutanan dan Perikanan tersebut selain dapat memenuhi kebutuhan wilayah sendiri juga dapat mengekspor produknya ke luar wilayah. Tahun 2014 sampai 2018 penurunan LQ cukup kecil. Sektor Pertanian, Kehutanan dan Perikanan, Perkebunan dan Perikanan menjadi sektor basis dalam perekonomian Kabupaten Aceh Tenggara karena didukung oleh keadaan geografisnya. Sebagian besar lahan di Kabupaten Aceh Tenggara adalah 
lahan pertanian, perkebunan dan perikanan semakin luas penggunaan lahan di sektor sektor tersebut maka semakin tinggi potensi produksi yang dihasilkan.

\section{SIMPULAN}

Sektor pertanian, kehutanan dan perikanan, perkebunan merupakan sektor basis dalam perekonomian di Kabupaten Aceh Tenggara yang ditunjukkan dengan nilai rata-rata LQ 42,234. Perubahan posisi sektor pertanian, kehutanan dan perikanan yang terjadi di Kabupaten Aceh Tenggara adalah sektor pertanian, kehutanan dan perikanan diperkirakan tetap basis pada masa sekarang dan masa yang akan datang. Sektor pertanian, kehutanan dan perikanan Kabupaten Aceh Tenggara dan sub-sub sektonya memberikan peranan yang sangat penting terhadap pertumbuhan perekonomian di Provinsi Aceh ditunjukan dengan nilai rata-rata 1,2 Millyar.

\section{DAFTAR PUSTAKA}

BPS. Aceh Tenggara. (2019). Analisis Pertumbuhan Ekonomi Aceh Tenggara.

https://peraturan.bpk.go.id/Home/Details/45373/uu-no-41-tahun-1999.

https://id.m.wikipedia.org/wiki/perikanan diunduh pada 03 November 2019 pukul 20.00 WIB.

Putong, Iskandar. (2005). Teori Ekonomi Mikro. Jakarta: Mitra Wacana Media. hal. 93.

Latumaresa, Julius. (2015). Perekonomian Indonesia Dan Dinamika Ekonomi Global. Jakarta: Mitra Wacana Media, hal. 308.

Subandi. (2008). Sistem Ekonomi Indonesia. Bandung : Alfabeta.

Tambunan, Tulus. (2001). Perekonomian Indonesia. Jakarta: Ghalia Indonesia.

Tarigan, Robinson. (2003). Ekonomi Regional, Teori dan Aplikasi (edisi revisi). Jakarta: Bumi Aksara.

Tambunan, Tulus T.H. (2006). Perkembangan Sektor Pertanian Indonesia, Jakarta : Ghalia Indonesia.

Yantu, M.R 2012. Peran Sektor Pertanian, Kehutanan dan Perikanan dalam Perekonomian Kawasan Poso Sulteng: Suatu Pendekatan Model Persamaan Simultan J. Agroland 19 (13). 